\title{
Paranavaí: Eleições 2016 e grupos políticos em
}

\section{disputa}

\section{Rafael Egidio Leal e Silva ${ }^{1}$ \\ Tiago Valenciano ${ }^{2}$}

- Enviado em 15/09/2016

- Aprovado em 18/09/2016
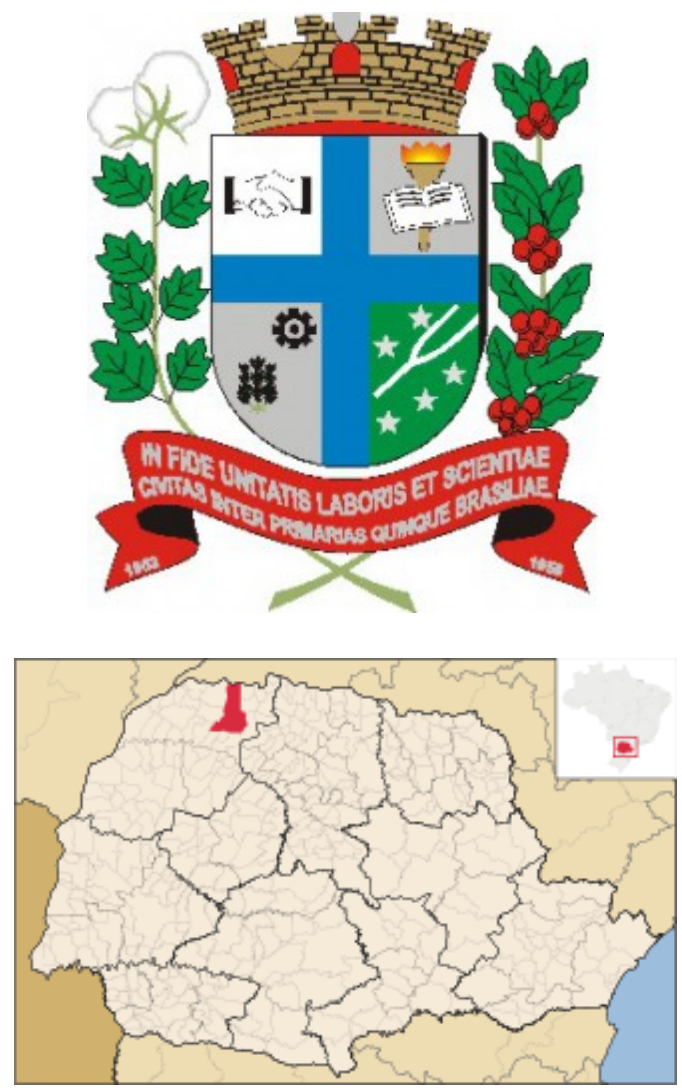

Fonte: http://paranavai.pr.gov.br:9900/.

Acesso 18.setembro.2016

\footnotetext{
1 Graduado em Ciências Sociais - Licenciatura (2008) pela Universidade Estadual de Maringá. É Mestre em Psicologia (2012) pela mesma Universidade. Atualmente é Docente RSC-III do Ensino Básico, Técnico e Tecnológico, atuando no eixo tecnológico "Ciências Humanas e suas tecnologias" na área de conhecimento de Sociologia no Instituto Federal do Paraná - Campus Umuarama. Endereço eletrônico: rafael.silva@ifpr.edu.br
}

2 Doutor em Sociologia pela Universidade Federal do Paraná (UFPR), Mestre e Graduado em Ciências Sociais pela Universidade Estadual de Maringá (UEM). Endereço eletrônico: tiagovalenciano.com 


\section{Paranavaí: Eleições 2016 e grupos políticos em disputa}

Rafael Egidio Leal e Silva

Tiago Valenciano

Paranavaí é uma cidade do noroeste do Estado do Paraná com população estimada de cerca de 87 mil habitantes e um total de 62.287 eleitores em 2016. Deste total, serão 47\% de homens, e $53 \%$ de mulheres.

Chama a atenção as estatísticas em relação ao nível educacional dos eleitores: 30,58\% possuem Ensino Fundamental Incompleto. Com Ensino Fundamental Completo: 7,12\%. Ensino Médio Incompleto: 22,11\%; e Ensino Médio Completo: 18,11\%. Eleitores com Ensino Superior Incompleto: 4.6\%; Ensino Superior Completo: 6,55\%. Analfabetos e pessoas que "leem e escrevem", cerca de 10\%. Notamos que o eleitorado predomina o baixo nível de instrução, o que contrasta com o nível de instrução dos candidatos, tanto a prefeitos, viceprefeitos e a vereadores, a maioria com Ensino Médio Completo (38\%) e Ensino Superior Completo (35\%), contraste este que se repete em outros municípios da região. 0 município conta com 05 candidatos a prefeito e 104 candidatos a vereador.

A Coligação "O caminho seguro" reúne os seguintes partidos: PSDB, PSD, PV, PRTB, PHS, PSL, PTB, PRB, PSC, SD, PC do B. O candidato a prefeito é Carlos Henrique Rossato Gomes (PSDB), o Delegado Caíque. Sua candidata à vice-prefeita, Jeanne Maria Fujii Kato (PSD) é esposa do empresário e do segundo suplente de Deputado Federal Teruo Kato (PMDB), que já foi prefeito de Paranavaí e teve dois mandatos na Câmara Estadual (20072010 e 2011-2014). Teruo aparece como doador na campanha, assim como o atual prefeito do município, Rogério Lorenzeti (PMDB).

A coligação "Paranavaí Ideal” tem como partidos integrantes o PMDB, PMN, PDT, PT, PROS, e tem como candidato a prefeito Waldir Tetilla (PMDB), que já ocupou o cargo de Secretário de Saúde do município e faz sua estreia em eleições. Seu candidato a vice-prefeito é Roberto Cauneto Picoreli (PMN), conhecido na cidade como Pó Royal, e que é experiente na política local como vereador. 0 atual prefeito do município, Rogério Lorenzeti é do PMDB, mas não se manifestou publicamente apoiando a chapa, embora também apareça como doador 
pessoal da campanha. Segundo o candidato Tetilla, sua filiação ao PMDB ocorreu por influência do ex-deputado Teruo Kato.

A coligação "Renovação com experiência" tem como integrantes os seguintes partidos: PP, PSB, PR, PPS. DEM. O candidato a prefeito é Maurício Yamakawa (PP), que foi prefeito de Paranavaí entre 2005 e 2008. Seu candidato a vice-prefeito é Fernando Siqueira de Carvalho (PSB). Entre os doadores de sua campanha, aparecem membros da família Dal Prá, do exdeputado federal (pelo PFL) e deputado constituinte (1987-1988) Dionísio Assis Dal Prá (1929-2014), que foi também prefeito de Paranavaí entre 1969 e 1972 pela Arena.

O PSOL tem como candidato Israel de Moraes, que faz sua primeira campanha eleitoral, aos 24 anos. Seu candidato a vice-prefeito é Antônio Carlos Ferreira. O PSTU lançou o candidato Ivan Bernardo, que disputa a prefeitura pela segunda vez. Seu candidato a viceprefeito é Marcos Aurélio.

Notamos que as principais coligações no município de Paranavaí refletem também os principais grupos políticos que disputam o poder da cidade. Para além da disputa partidária, a disputa familiar é nítida pelo poder local, onde atores tradicionais disputam espaço com novas figuras e grupos que emergem nas disputas de poder. 